\title{
Combustion of producer gas from gasification of south Sumatera lignite coal using CFD simulation
}

\author{
Fajri Vidian $^{1 *}$, Novia $^{2}$, Andy Suryatra $^{1}$ \\ ${ }^{1}$ Mechanical Engineering Department, Faculty of Engineering, Universitas Sriwijaya, 30662 Inderalaya, Indonesia. \\ ${ }^{2}$ Chemical Engineering Department, Faculty of Engineering, Universitas Sriwijaya, 30662 Inderalaya, Indonesia.
}

\begin{abstract}
The production of gasses from lignite coal gasification is one of alternative fuel for the boiler or gas turbine. The prediction of temperature distribution inside the burner is important for the application and optimization of the producer gas. This research aims to provide the information about the influence of excess air on the temperature distribution and combustion product in the non-premixed burner. The process was carried out using producer gas from lignite coal gasification of BA 59 was produced by the updraft gasifier which is located on Energy Conversion Laboratory Mechanical Engineering Department Universitas Sriwijaya. The excess air used in the combustion process were respectively $10 \%, 30 \%$ and $50 \%$. CFD Simulations was performed in this work using two-dimensional model of the burner. The result of the simulation showed an increase of excess air, a reduction in the gas burner temperature and the composition of gas (carbon dioxide, nitric oxide and water vapor).
\end{abstract}

\section{Introduction}

The decreasing of crude oil as the energy sources has been followed by the increasing of the energy needs, so the needs of an alternative energy source to replace the crude oil is very crusial. Coal is one of the alternative energy to replace the crude oil. The utilization of coal in the direct combustion method will cause a problem in the pollution and a low efficiency of energy conversion. Gasification is one of the technology that can convert coal to be combustible gas with the low pollution [1-2] and high of the efficiency [2-3]. Indonesia is one of the largest coal-producing country in the world that have coal reserves about $3 \%$ from the world coal reserve [4] whereis about $57 \%$ of the reserve is the lignite coal [5]. South Sumatera is one of the largest coal suppliers in Indonesia. One of the coal product that not utilized maximally is the lignite coal (South Sumatera lignite coal called as BA 59).

The combustible gas produced from its gasification can be used for application on boiler, gas turbine, and dryer [6]. Its for the coal application, it needs an appropriate gas burner to reach the temperature distribution as expected. The method can be used to predict the temperature distribution inside the gas burner is simulation using computational fluid dynamics. Several simulations has been done by several researchers. Previous authors [7] has simulated the combustion of producer gas from the biomass gasification using computational fluid dynamics (CFD). The result of study shows the highest temperature is about $1367{ }^{\circ} \mathrm{C}$. Other researchers [8] has simulated the combustion of producer gas from biomass gasification, the result shows the highest temperature in the combustion chamber about $1300{ }^{0} \mathrm{~K}$ to $1700{ }^{0} \mathrm{~K}$. The combustion of producer gas in gas burner for applying in gas turbine is reported by [9]. The result of the work showed that the highest temperature of combustion was about $1500{ }^{\circ} \mathrm{K}$ [9].

Another work have performed by [10], they simulated the combustion of producer gas from gasification of wood chip and turkey feather.The result showed that the highest temperature can reach to 2000 ${ }^{0} \mathrm{~K}$ and $1500{ }^{0} \mathrm{~K}$ [10]. The combustion of producer gas from coconut shell gasification at swirl gas burner has simulated by [11], the result shows the application of swirl will increase the combustion temperature. The highest temperature reached about $1173^{\circ} \mathrm{K}$ [11]. The result of the researchers showed the combustion temperature of the producer gas is effected by the fuel of the gasification process and the gas burner design with the temperature range of $1200{ }^{\circ} \mathrm{K}$ to $2000{ }^{\circ} \mathrm{K}$. However, none of the previous studies used the application of CFD on the production of gassesfrom lignite coal gasification. The objective of this research is to obtaint he effect of excess air on the temperature distribution and the combustion products in the non-premixedburner using CFD simulation.

\section{Producer gas composition}

Producer gas used in the simulation is the BA 59 that produced from coal gasification from South Sumatera, Indonesia using updraft gasifier at Energy Conversion Laboratory Mechanical Engineering Department,

\footnotetext{
*Corresponding author: fajri.vidian@unsri.ac.id
} 
Sriwijaya University. The gas composition shows in Table 1.

Table 1. Producer gas composition

\begin{tabular}{|c|c|}
\hline Species & $\%(\mathrm{Vol})$ \\
\hline $\mathrm{CO}$ & 29.54 \\
\hline $\mathrm{H}_{2}$ & 12.07 \\
\hline $\mathrm{CH}_{4}$ & 3.4 \\
\hline $\mathrm{CO}_{2}$ & 8.11 \\
\hline $\mathrm{O}_{2}$ & 1.3 \\
\hline $\mathrm{N}_{2}$ & 45.58 \\
\hline
\end{tabular}

\section{Governing equation}

Combustion process of the producer gas at the stoichiometry condition define by the equation below

$$
\begin{aligned}
& \text { producergas }+0.26305\left(\mathrm{O}_{2}+3.76 \mathrm{~N}_{2}\right) \\
& \rightarrow 0.4105 \mathrm{CO}_{2}+0.1887 \mathrm{H}_{2} \mathrm{O}+1.4449 \mathrm{~N}_{2}
\end{aligned}
$$

Combustion of producer gas in gas burner involved fluid flow and chemical reaction. Mass and momentum equation are used to drive the fluid flow.

Mass Conservation Equation

$\frac{\partial \rho}{\partial t}+\nabla \cdot(\rho \vec{v})=S_{m}$

Momentum Conservation Equation

$\frac{\partial}{\partial t}(\rho \vec{v})+\nabla(\rho \vec{v} \vec{v})=-\nabla p+\nabla \overline{\bar{\tau}}+\rho \bar{g}+\bar{F}$

The distribution temperature inside gas burner is solved by energy conservation equation.

$$
\begin{aligned}
& \frac{\partial}{\partial t}(\rho E)+\nabla(\vec{v}(\rho E+p))=\nabla\left(k_{e f f} \nabla T-\sum_{j} h_{j} \vec{J}_{j}+\right. \\
& \left.\left(\overline{\bar{\tau}}_{e f f} \vec{v}\right)\right)+S_{h}
\end{aligned}
$$

Species movement in the gas burner is solved using the species transport equation

$\frac{\partial}{\partial t}\left(\rho Y_{i}\right)+\nabla\left(\rho \vec{v} Y_{i}\right)=-\nabla \cdot \bar{J}_{i}+R_{i}+S_{i}$

The combustion process depend on the turbulence. $\mathrm{K}$-Epsilon Standard equation is used to solve turbulence processd uring combustion.

$\frac{\partial}{\partial t}(\rho k)+\frac{\partial}{\partial x_{i}}\left(\rho k u_{i}\right)=\frac{\partial}{\partial x_{j}}\left[\left(\mu+\frac{\mu_{t}}{\sigma_{k}}\right) \frac{\partial k}{\partial x_{j}}\right]+G_{b}+G_{k}-$

$\rho \varepsilon-Y_{M}+S_{k}$
The interaction between chemical reaction and turbulence in side of the gas burner are solved using the model has developed by Magnussen and Hjertager. The reaction rate will be produced by the smallest value between equation 7 and 8 .

$R_{i, r}=v_{i, r}^{\prime} M_{w, i} A \rho \frac{\varepsilon}{k} \min _{R}\left(\frac{Y_{R}}{v_{R, r}^{\prime} M_{w, R}}\right)$

$R_{i, r}=v_{i, r}^{\prime} M_{w, r} A B \rho \frac{\varepsilon}{k} \frac{\sum_{P} Y_{P}}{\sum_{J}^{N} v_{j, r} M_{w, j}}$

The mechanism of NOx production in side gas burner are modeled on thermal and prompt mechanism.

Thermal NOx mechanism

$$
\begin{aligned}
& \mathrm{O}+\mathrm{N}_{2} \geq \mathrm{N}+\mathrm{NO} \\
& \mathrm{N}+\mathrm{O}_{2} \geq \mathrm{O}+\mathrm{NO} \\
& \mathrm{N}+\mathrm{OH}=\mathrm{H}+\mathrm{NO}
\end{aligned}
$$

Prompt NOx mechanism

$$
\begin{gathered}
\mathrm{CH}+\mathrm{N}_{2}=\mathrm{HCN}+\mathrm{N} \\
\mathrm{N}+\mathrm{O}_{2} \geq \mathrm{NO}+\mathrm{O} \\
\mathrm{HCN}+\mathrm{OH} \geq \mathrm{CN}+\mathrm{H}_{2} \mathrm{O} \\
\mathrm{CN}+\mathrm{O}_{2} \geq \mathrm{NO}+\mathrm{CO}
\end{gathered}
$$

Thermal and Prompt NOx transport are derived by equation below.

$$
\frac{\partial}{\partial t}\left(\rho Y_{N O}\right)+\nabla \cdot\left(\rho \vec{v} Y_{N O}\right)=\nabla \cdot\left(\rho \mathcal{D} \nabla Y_{N O}\right)+S_{N O}
$$

\section{CFD Modeling}

The combustion process was conducted in non premixed gas burner with the diameter of $45 \mathrm{~cm}$ and length of 180 $\mathrm{cm}$ [12]. The nozzle for injecting the producer gas diameter of $1 \mathrm{~cm}$ [12]. The schematic of of the gas is presented burner in Fig 1.

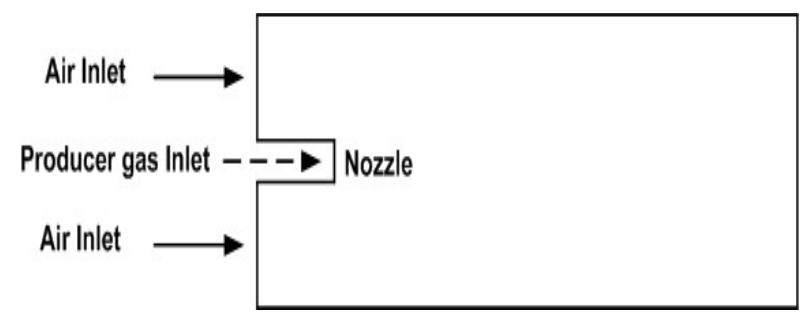

Fig.1. The scheme of gas burner

The simulation process was done in 2D of gas burner using ANSYS Fluent 16. The gas burner for domain of the calculation must be mesh to solve all the equation. The equations were solved using finite volume method. The construction of meshing are showed in Fig 2 and Fig 3. 


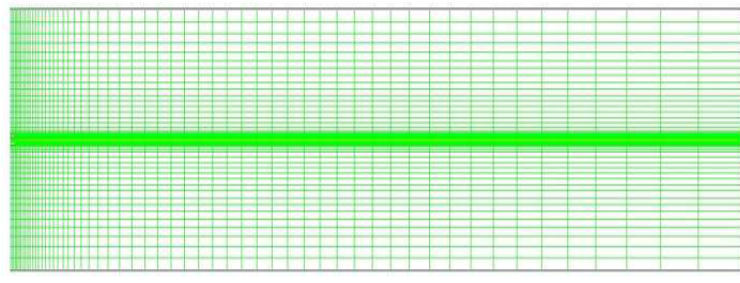

Fig.2. Mesh of the gas burner

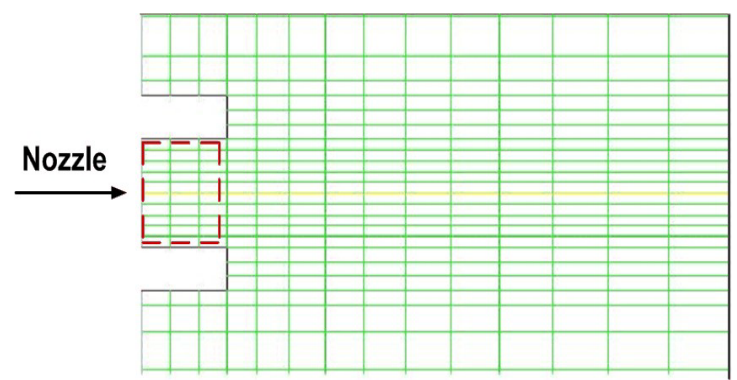

Fig.3. Mesh of the nozzle

The boundary condition for the simulation is presented in Table 2.

Table 2. Boundary Condition of The Simulation

\begin{tabular}{|l|l|c|}
\hline \multicolumn{1}{|c|}{ Paremeter } & \multicolumn{1}{|c|}{ Condition } & Quantitity \\
\hline $\begin{array}{l}\text { Velocity of } \\
\text { Producer gas }\end{array}$ & $\begin{array}{l}\text { Excess air of } \\
0 \% ; 10 \% ; 30 \% ; 50 \%\end{array}$ & $80 \mathrm{~m} / \mathrm{s}$ \\
\hline Velocity of air & Excess of air $0 \%$ & $0.052 \mathrm{~m} / \mathrm{s}$ \\
\hline Velocity of air & Excess of air $10 \%$ & $0.057 \mathrm{~m} / \mathrm{s}$ \\
\hline Velocity of air & Excess of air $30 \%$ & $0,067 \mathrm{~m} / \mathrm{s}$ \\
\hline Velocity of air & Excess of air $50 \%$ & $0.077 \mathrm{~m} / \mathrm{s}$ \\
\hline $\begin{array}{l}\text { Inlettemperatur } \\
\text { e of } \\
\text { producergas }\end{array}$ & $\begin{array}{l}\text { Excess air of } \\
0 \% ; 10 \% ; 30 \% ; 50 \%\end{array}$ & $300^{0} \mathrm{~K}$ \\
\hline $\begin{array}{l}\text { Inlettemperatur } \\
\text { e of air }\end{array}$ & $\begin{array}{l}\text { Excess air of } \\
0 \% ; 10 \% ; 30 \% ; 50 \%\end{array}$ & $300{ }^{0} \mathrm{~K}$ \\
\hline
\end{tabular}

\section{Result and discussion}

\subsection{Temperature distribution}

The simulation result shows the increasing of excess air from 0 to $50 \%$ will reduce the temperature distribution in gas burner as shown in Fig 4. The increasing amount of air caused the increasing amount of nitrogen. This is due to nitrogen absorb the heat from combustion and reduce the temperature in gas burner. This result is similar with the study as reported by [13-14]. The highest temperature was about of $1910{ }^{\circ} \mathrm{K}$. The temperature was decreased about of $100{ }^{0} \mathrm{~K}$ for increasing of the excess air from $0 \%$ until $50 \%$.

In the visualization can be shown clearly the reduction of temperature distribution in the gasburner as shown in figure 5-8. The reduction zone of the yellow contour which describe the higher temperature, other wise increasing of the green zone which describe the lower temperature zone.

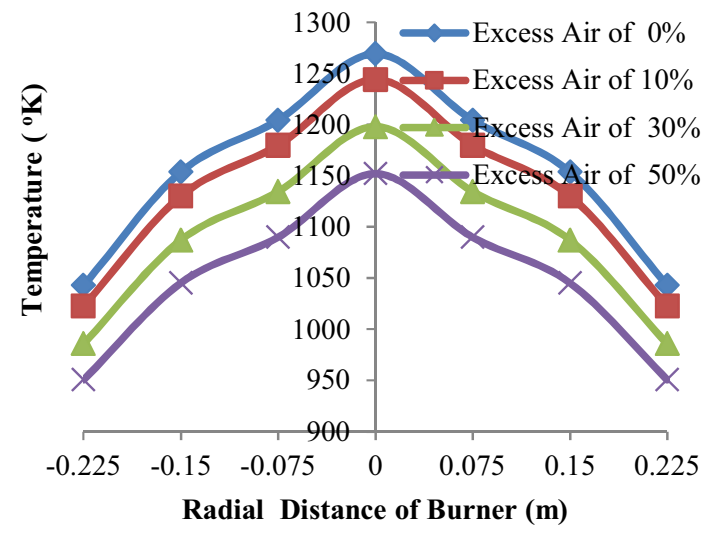

Fig. 4. Temperature distribution on middle of burne rat radial distance with difference of excess air

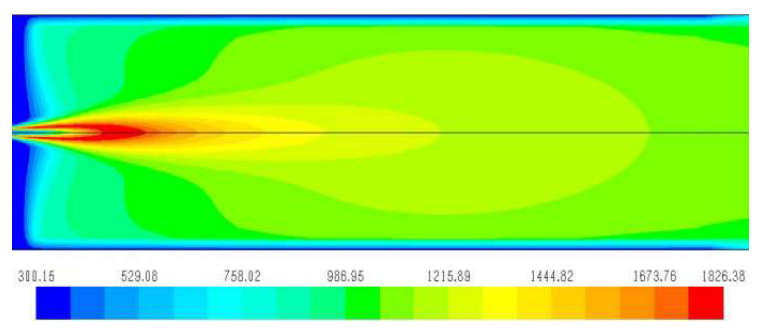

Fig.5. Temperature distribution on excess air of $0 \%$

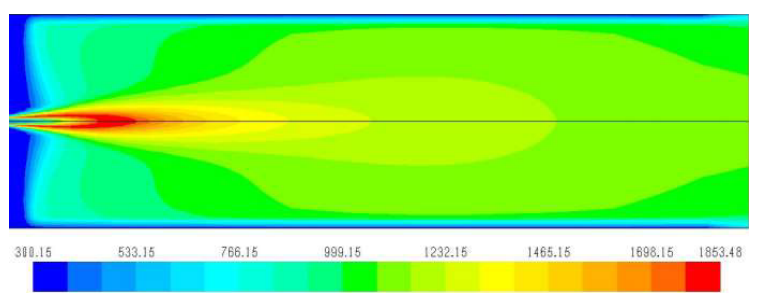

Fig.6. Temperature distribution on excess air of $10 \%$

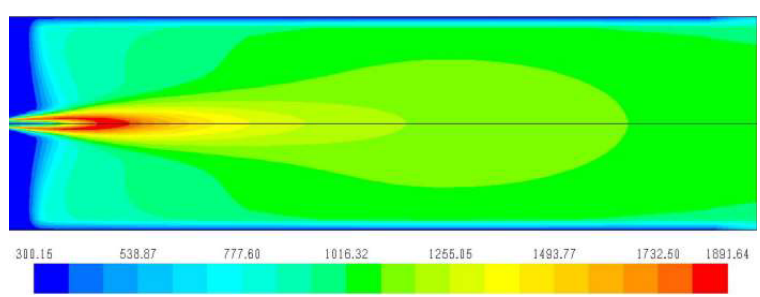

Fig.7. Temperature distribution on excess air of $30 \%$

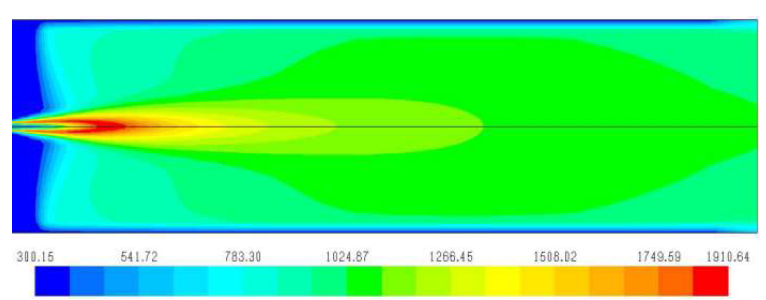

Fig.8. Temperature distribution on excess air of $50 \%$ 


\subsection{Carbon dioxide $\left(\mathrm{CO}_{2}\right)$ distribution}

From the simulation, it showed that the excess air was increased with the decreased of the concentration distribution of $\mathrm{CO}_{2}$ in gas burner as shown in Fig 9. This condition was occurred due to the increasing of air which is not followed by the increasing of carbon content in combustion process when the fuel flow rate is set constant. The result showed the same trend with the result has been reported by [15].

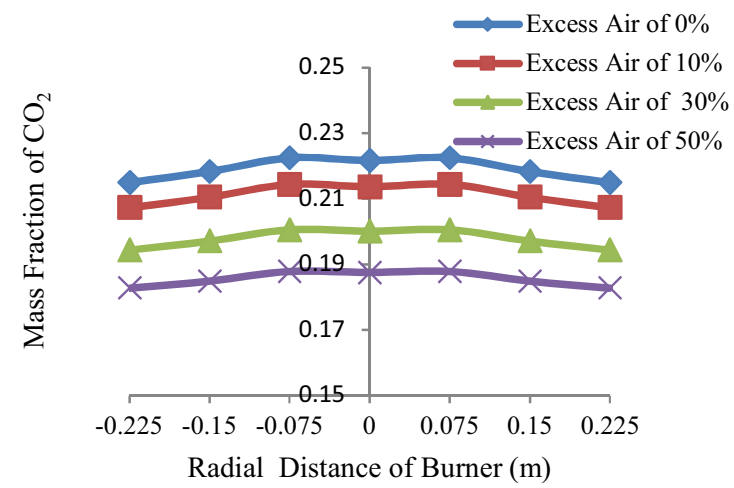

Fig. 9. Carbon dioxide distribution on middle of gas burner at radial distance with difference excess air.

The decreasing of $\mathrm{CO}_{2}$ distribution in gas burner is shown clearly in Fig. 10-13. The area of highest temperature (brown color) shown a decrease as the increase of the excess air. The maximum of $\mathrm{CO}_{2}$ mass fraction concentration could be reached to $28 \%$. The increasing of excess air from $0-50 \%$ caused a decrease in mass fraction concentration about $3 \%$.

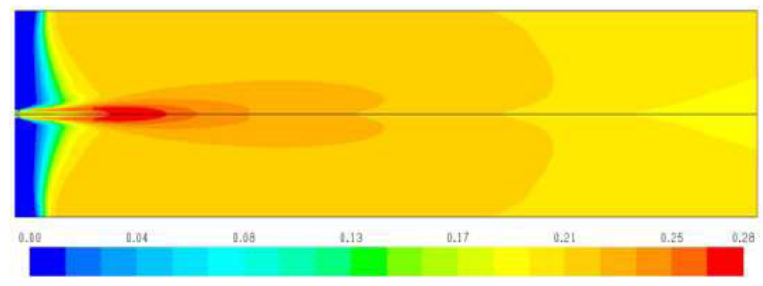

Fig.10. Carbon dioxide distribution in gas burner on excess air of $0 \%$.

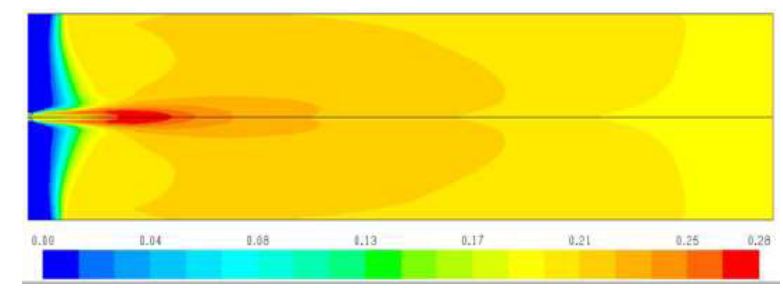

Fig.11. Carbon dioxide distribution in gas burner on excess air of $10 \%$.

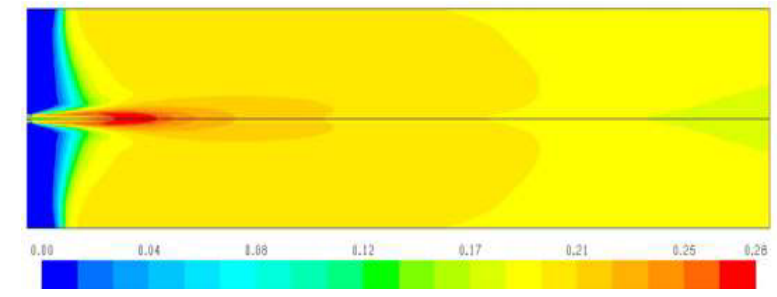

Fig.12. Carbon dioxide distribution in gas burner on excess air of $30 \%$.

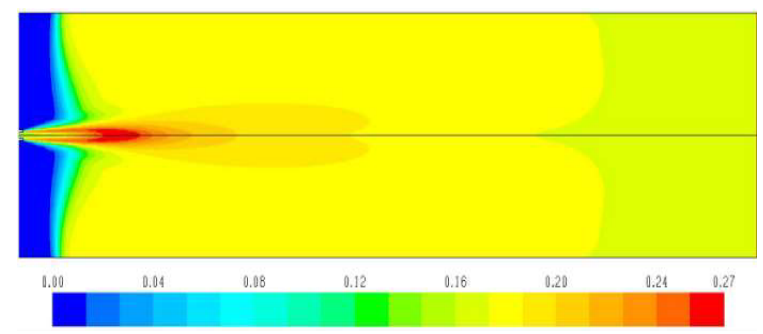

Fig.13. Carbon dioxide distribution in gas burner on excess air of $50 \%$.

\subsection{Water vapor $\left(\mathrm{H}_{2} \mathrm{O}\right)$ distribution}

The simulation result shows the increasing of excess air will decrease the distribution of $\mathrm{H}_{2} \mathrm{O}$ in gasburner as shown in Fig 14, it is caused by the increasing of excess air was not followed by the increasing of $\mathrm{H}_{2}$ (constant of fuel flow rate).

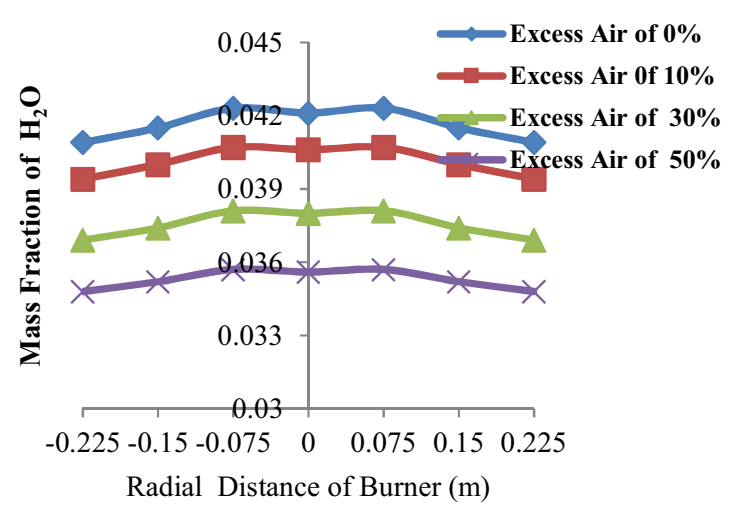

Fig. 14. Water vapor distribution on middle of gas burner at radial distance with difference excess air.

The decreasing of $\mathrm{H}_{2} \mathrm{O}$ distribution in gas burner is shown clearly in Fig 15-18. The area of highest temperature (brown color) shown a decrease as the increase of excess air. The maximum of $\mathrm{H}_{2} \mathrm{O}$ mass fraction concentration could be reached to $5 \%$. The increasing of excess air from $0 \%-50 \%$ caused a decrease in mass fraction concentration about $0.6 \%$. 


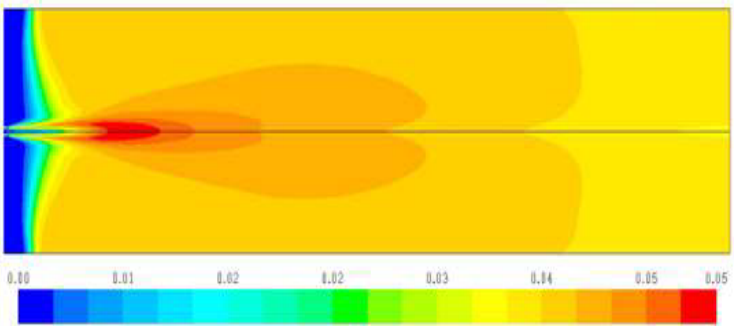

Fig. 15. Water vapor distribution in gas burner on excess air of $0 \%$

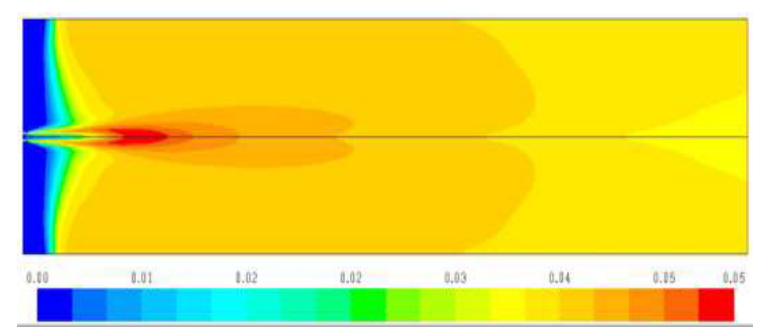

Fig. 16. Water vapor distribution in gas burner on excess air of $10 \%$

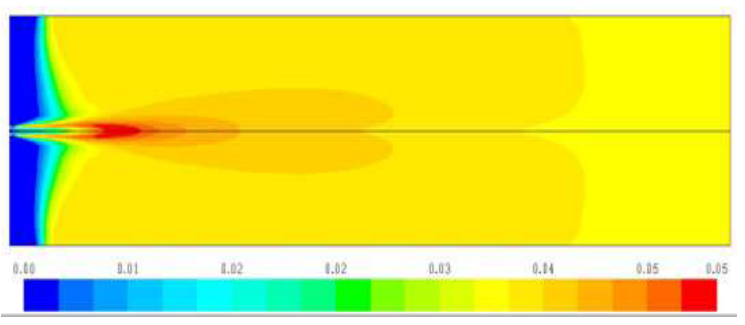

Fig. 17. Water vapor distribution in gas burner on excess air of $30 \%$

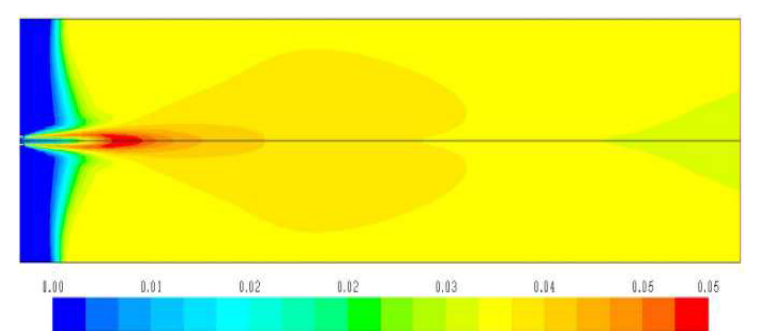

Fig. 18. Water Vapor distribution in gas burner on excess air of $50 \%$

\subsection{Nitric Oxide (NO) distribution}

From the simulation process it shown an increase in excess air will caused a decrease in NO distribution in gas burner as shown in Fig 19. It is caused by the increasing of excess air which is followed by the decreasing of temperature in gas burner as shown in figure 4.The reaction $9-15$ is decreased by the decreasing of temperature. This result has similarity to the simulation has reported by [16].

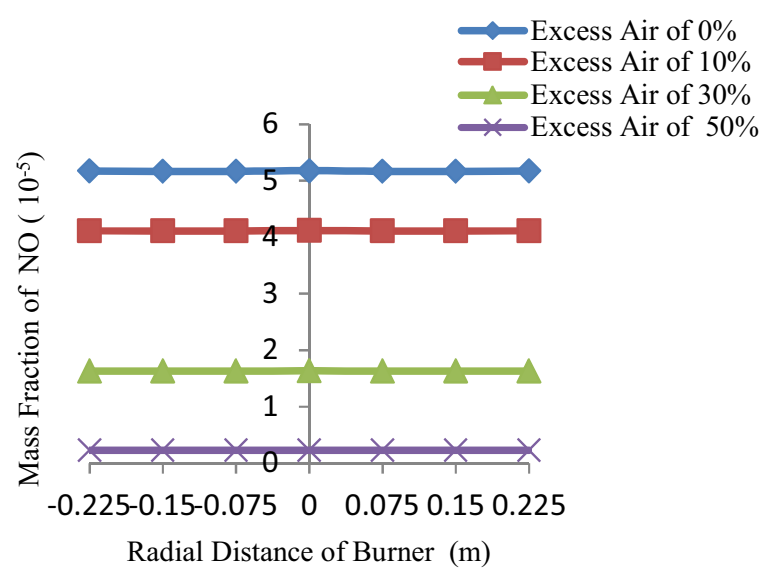

Fig. 19. Nitric Oxide distribution on middle of gas burner at radial distance with difference excess air.

The decreasing of NO distribution in gas burner shows in the visualization of contour in figure 20-23. It can be seen clearly the decreasing of the area of red contour (The highest of NO concentration) as the effect of the increasing of excess air. The maximum mass fraction of NO was about $5.37 \times 10^{-3} \%$. The increasing of excess air from $0 \%$ until $50 \%$ will decrease mass fraction concentration about of $4.9 \times 10^{-3} \%$.

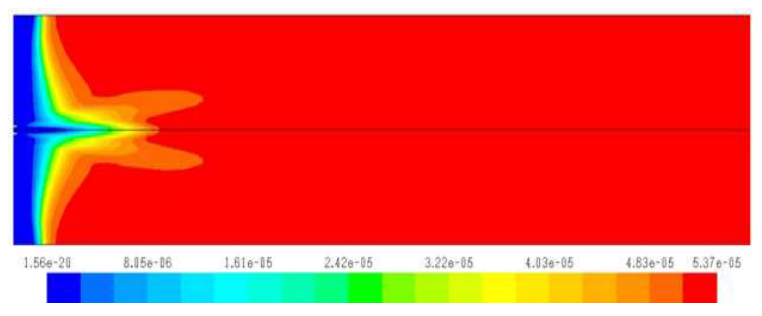

Fig. 20. Nitric oxide distribution in gas burner on excess air of $0 \%$

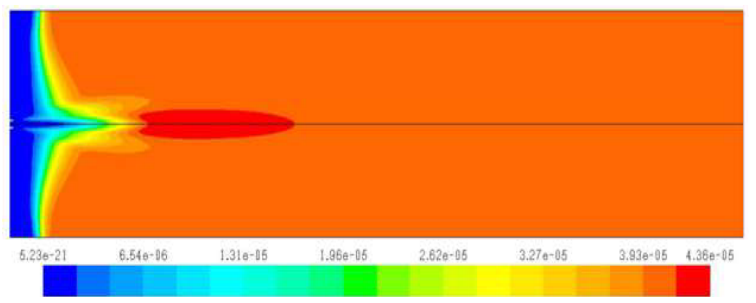

Fig. 21. Nitric oxide distribution in gas burner on excess air of $10 \%$

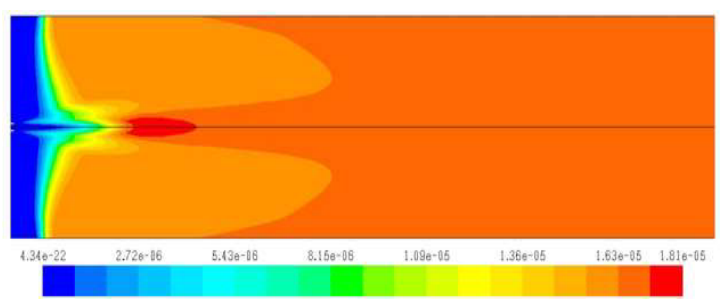

Fig. 22. Nitric oxide distribution in gas burner on excess air of $30 \%$ 


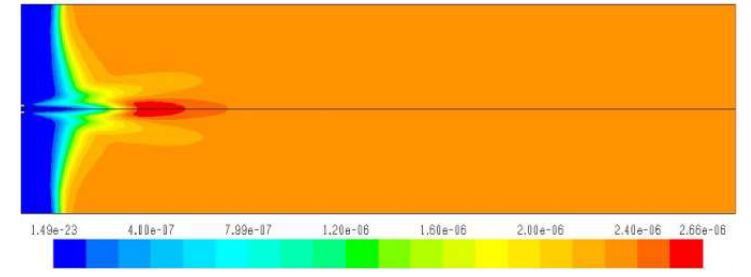

Fig. 23. Nitric oxide distribution in gas burner on excess air of $50 \%$

\section{Conclusion}

From the simulation, a numberof conclusions couldbetakenas follow:

- The highest temperature can be reached by the combustion of producer gas from gasification of BA 59 coal at non premixed gas burner is $1910{ }^{\circ} \mathrm{K}$, The highest mass fraction concentration of $\mathrm{CO}_{2}$ about $28 \%$, and the highest mass fraction concentration of NO about $5.37 \times 10^{-3} \%$.

- The increasing of excess air on combustion process from $0 \%-50 \%$ will cause the decreasing of temperature, $\mathrm{CO}_{2}, \mathrm{H}_{2} \mathrm{O}$, and $\mathrm{NO}$ distribution in side gas burner

\section{References}

1. Y. Yun, S.W. Chung, Korean Journal Chemical Engineering, 24 (4), 628-632, (2007).

2. N. Crnomarkovic, B. Repic, R. Mladenovic, O. Neskovic, M.Veljkovic, Fuel, 86, 194-202, (2007).

3. A.G. Collot, International Journal of Coal Geology, 65, 191-216, (2006).

4. T. Winarno, C.Drebenstedt,Mine Planning
Equipment Selection, Springer International Publishing Switzherland, 1495-1494,(2014).

5. Asia Pacific Economic Corporation, Final Report, 1-67, (2013).

6. E.G. Pereira , J.N. Dasilva, J.L. Olievera, C.S. Machado, Renewable Sustainable Energy Reviewas, 16, 4753-4762, (2015).

7. P. P. Ushekwar, S. B. Desai, M.M. Wagh, N. N. Shinde, International Research Journal of Engineering and Technology, 2(4), 1621-1624, (2015).

8. Y. Achawangkul, N. Maruyama, M. Hirota, C. Chaichana, T. Sutabutr, IOSR Journal of Engineering, 4(2), 17-23, (2014).

9. G.S. Sharma, M.V.S.M. Krishna, D.N. Reddy, International Journal of Mechanical and Production Engineering Research and Development, 5(2), 21-32, (2015).

10. K. Kwiatkowski, M. Dudynski, K. Bajer, Flow Turbulence Combustion, 91, 749-772, (2013).

11. A.Surjosatyo, Y. D. Priambodho, International Journal JurnalMekanikal, 33, 15- 31, (2011).

12. Fluent, Incorporated : Fluent 6 UDF Manual, Lebanon (NH), Fluent Inc, 2001.

13. H.F. Elattar, R. Stanev, E. Specht, A. Fouda, “ Computer and Fluids, 102, 62-73,(2014).

14. R.K. Jain, IPASJ International Journal of Mechanical Engineering, Vol 2 (3), 20-28, (2014)

15. J.C. Lou, C.C. Huang, T.L. Yang, Journal of The Chinese Institute of Environmental Engineering, 9 (4), 219-227, (1999).

16. A.Soid, W. Kriaa, H. Mhiri, G.L. Palec, P. Bournot, Proceeding of Word Congress on Engineering 2009, Vol II WCE,July 1-3, London UK, (2009) 